1997 年 2 論文受付 論文受理 1997年 7 月 4 日

Code No.730
荒居広明

心臓血管研究所付属病院放射線部

\section{1. 序 言}

冠動脈疾患の増加に伴い，血管造影法を治療に応用 したinterventional angiographyが盛んに行われるよう になった、X線シネ撮影では種々の撮影方向やX線イ メージインテンシファイア(以下，I.I.)の視野サイズ が用いられるが，常に一定のフィルム濃度が要求され るため自動露出制御が必須である。また，視野内の 造影剂量の変化や被写体の移動による被写体厚の変
化など，時間的な変化に対しても迅速な応答が要求さ れる1,2)。

当施設では同一メーカで自動露出制御装置が異なる 新旧 2 台のX線シネ撮影装置を有する。これらの装置 の自動露出制御装置の被写体厚特性と, 被写体厚が変 化したときの応答特性を測定し解析した。

\title{
X-ray Conditions and Response Characteristics of Automatic Dose Control in Cinematography
}

HIROAKI ARAI

Department of Radiology, Cardiovascular Institute Hospital

Received Feb.5,1997; Revision accepted Jul.4,1997; Code No.730

\section{Summary}

X-ray characteristics including subject thickness (copper plate), tube voltage, tube current and irradiation time were measured at stability, with an automatic dose control $\mathrm{x}$-ray generator for cineangiography. Regardless of subject thickness, it is possible that the energy input to the $\mathrm{X}$-ray tube in one frame may be decreased. The automatic control response was measured after rapid fluctuation in subject thickness. Two inverter-type $x$-ray generators with different automatic control units were studied. The older control unit changes exposure dose by tube voltage and tube current, while the newer one changes exposure dose by tube voltage, tube current and irradiation time. The maximum rate of change in tube voltage is greater with the newer control unit. In addition, the actual tube current response of the newer control unit in increasing nominal value is faster than the older one. In the new control unit, for each pulse, irradiation is cut off by means of a signal that the exposure has reached the proper value. Thus given the same differential in subject thickness, the newer control unit resumed stability faster than the older one.

Key words: Automatic dose control, Cinematography, Inverter type x-ray generator,

Response characteristic, $X$-ray condition characteristics 


\section{X線㓤置および測定器}

\section{2-1 X線装置}

装置 1

X線高電圧装置：POLYDOROS 100

X線管装置：Megalix 125/30/82CM-120LW

I.I.

: Optilux27HD-Triplex

装置 2

X線高電圧装置：POLYDOROS IS

X線管装置 ：Megalix125/30/82CM-120GW

I.I.

: SIRECON 23-3DR

(以上，シーメンス旭メディテック株式会社製)

\section{2-2 測定器}

管電圧，管電流波形記録計：

Memory Hi-Corder 8813 (4ch)

（日置電機株式会社製）

得られた波形上での面積計算は，Power Macintosh 8500 コンピュータ上で，パブリックドメインソフトの NIH-imageを用いて行った[U.S. National Institutes of HealthのWayne Rasband製 zippy.nimh.nihgovにanonymous FTPで入るか, NTIS (5285 Port Royal Rd., Springfield, VA22161, part number PB93-504868) か らフロッピーディスクで入手できる].

\section{2-3 その他}

被与体

: 銅板 $200 \mathrm{~mm} \times 200 \mathrm{~mm}$

厚さ $0.5 \mathrm{~mm} 10$ 枚, $1 \mathrm{~mm} 5$ 枚, $2 \mathrm{~mm} 2$ 枚

フィルム

: MI-CGC 現像液XCD-1

ソフナー $20 \mathrm{cc} / 1$

(富士写真フィルム株式会社製)

Average Gradient $1.38 \sim 1.42$

\section{3. 自動露出制御のための入力信号検出}

一般に自動露出制御のための入力信号として検出さ れる量は，X線量ではなく，I.I.の出力敛光面の光量の 一部である。これは, シネフィルム面への露光量に比 例する值であるため，この量を一定に保てば，適切な 現像処理により，常に一定のフィルム濃度が保証され る。またこの量がフィードバックされて，X線条件 が制御される。

\section{3-1 装置 1 の検出方法}

X線照射中は，I.I.の出力监光面像をTVモ二夕用の 撮像管僋とシネカメラ側に光束を分配して供給するた め，タンデムレンズとその中に設けられたハーフミラ 一が用いられる。このハーフミラーとは別に設けられ たミラーによって, 平行光束となった出力蛍光面光量
の一部を取り出してレンズで結像する，結像面に置か れた光学絞りで自動露出機構の採光野を設定して, 光 電子増倍管 (photomultiplier tube : 以下, PMT)により 光電流に変換して増幅し，1フレーム分を積分して保 持する。この值がフィードバックされてX線条件の制 御が行われる。

\section{3-2 装置 2 の検出方法}

I.I.の出力蛍光面像の一部を検出器に導く方法は, 装置 1 と同じであるが, 検出器には光半導体検出器 (photodiode array：以下, PDA)が用いられている。 光学絞りはなく, 検出面をいくつかの領域に分けて, 領域ごとに独立して光量を計測する。また，I.I.視野 サイズにより領域の組み合わせを変えて, それぞれに 関心領域を設定している。

\section{4. 方 法}

今回計測するX線シネ撮影の条件は，通常の冠動脈 造影に使用されるプリセット条件を選んだ。

装置 1 のプリセット条件は，7インチ視野，SID $90 \mathrm{~cm}$ (グリッドの集束距離), オートフォーカス (透視 時のX線条件から大，または小焦点を自動的に決定す る)，25F(フレーム)/s，撮影時間は公称 $4 \mathrm{~ms} / \mathrm{F}$ 固定で ある、装置 2 では，17cm視野，SID $95 \mathrm{~cm}$ (グリッド の集束距離)，大焦点固定， $30 \mathrm{~F} / \mathrm{s}$ で $1 \mathrm{~F}$ 当たりの撮影時 間は変化する。被写体は，X線管装置のコリメータボ ックスの直上に置いた。

\section{4-1 X線条件の被写体厚特性}

X線条件の被写体厚特性を求めるために銅板を被写 体として透視，シネ撮影の順で行い，X線条件が被写 体に対し適正で定常状態になった時の次に示す值を計 測した。

装置 1 では，管電圧と管電流の実測值，X線時限信 号，およひPMTの出力積分信号をサービス端子から計 測した。

装置 2 では，管電圧と管電流の実測值，およびX線 時限信号をサービス端子から，また，露光量に比例す るPDAからの出力の瞬時值をX線制御装置内の端子か ら計測した。

\section{4-2 自動露出機構の応答特性}

X線の被写体による減弱は，被写体の厚さと物質の 組成に依存する。また，被写体が移動した時にPMT が検出する光量は，自動露出の採光野との位置関係か ら時間的に変化するが，その仕方は様々である，今回 の測定では，応答特性に重点をおくため，I.I.の視野 内の被写体の厚さと組成はすべて均一と仮定した。そ 
して，シネ撮影中に銅板を抜き差しして，あるフレ 一ムを境に被写体が厚く，または薄くなる場合を設定 した。

4-1で求めた被写体厚特性から, 変化させる前の銅 板の厚さと抜き差しする厚さを決めた。その基準は, 被写体厚変化の前後で, 管電圧が変化する, 管電流が 変化する，および両者が変化するように決定した。そ して，被写体は4-1と同じ銅板を用いた。

予備実験で，装置 1,2 とも管電圧の実測值は設定 值(X線制御装置がX線高電圧装置に対して指令した 值)に正確に一致することを確かめた。また，以下の 応答特性計測時の各フレームの撮影時間は，記録した X線時限信号の時間を示す。

装置 1 では, PMTの出力積分值はフィルムへの露光 量に対応子るので, PMTの出力積分值とフィルム濃度 の関係を求めた。PMTの出力積分值の適正值の前後の 計測可能な值 $(0 \sim 10 \mathrm{~V})$ でのフィルム濃度を求めるた めに，自動露出制御の安定したところでシネ撮影を止 め, 被写体の銅板厚若干增やし(または減らし)て, 再びシネ撮影を開始する。そしてX線条件が変わって 適正になるまでの過渡期の各フレームのPMTの出力積 分值と現像処理後のフィルム濃度を測定して関係を求 めた。

応答特性の計測は，装置 1 では，管電圧の実測值， 管電流の設定值と奏測值，およびPMTの出力積分信号 を計測した。

装置 2 では，管電压の実測值，管電流の設定値と実 測值，X線時限信号を計測した。また，フィルムへの 露光量に対応する值(PDAの出力值)は瞬時值しか計測 できないので, 同時にX線シネ撮影を行い, 現像処理 をしてフィルム濃度を得た。

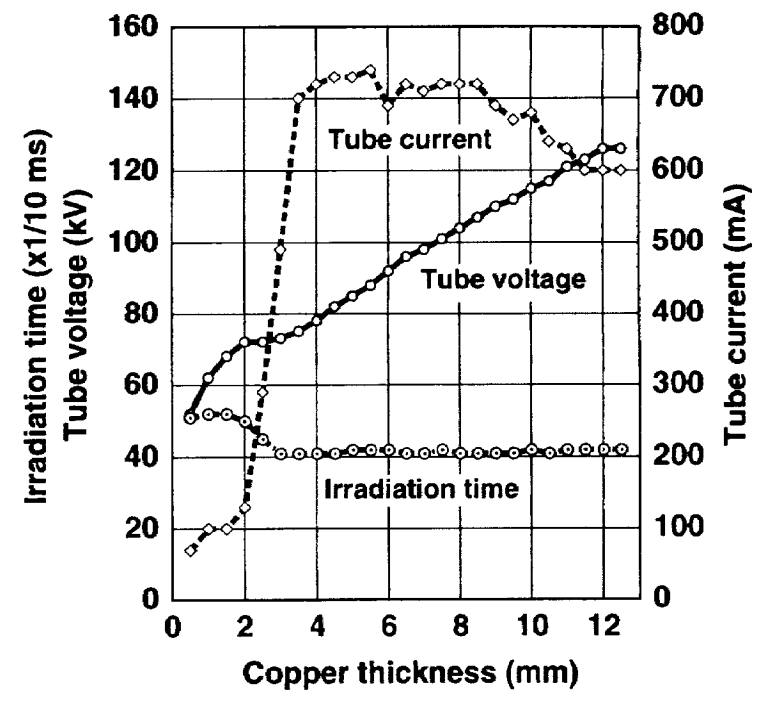

Fig. 1 Relationship between copper thickness and tube voltage, tube current and irradiation time at stability (apparatus 1).

\section{5. 湘定結果}

\section{5-1 X線条件の被写体厚特性}

装置 1 の特性をFig.1に示す。管電圧は，52kVから $126 \mathrm{kV}$ 範囲で変化する。X線焦点は銅板 $3 \mathrm{~mm}$ から大 焦点になる。X線時限信号は被写体厚によらず $4.4 \mathrm{~ms}$ であったが，管電流が300mA以下では管電圧の減衰が 遅く，撮影時間が5msを越えるものもある(Fig.2)。銅

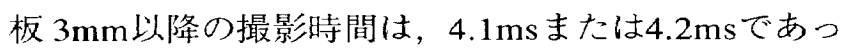
た。1F当たりにX線管に供給したエネルギ一として管 電圧，管電流，撮影時間の積をFig.3に示す。

装置 2 の特性をFig.4に示す。管電圧は64kVから $124 \mathrm{kV}$ 範囲で変化する。管電流は銅板 $2.5 \mathrm{~mm}$ から

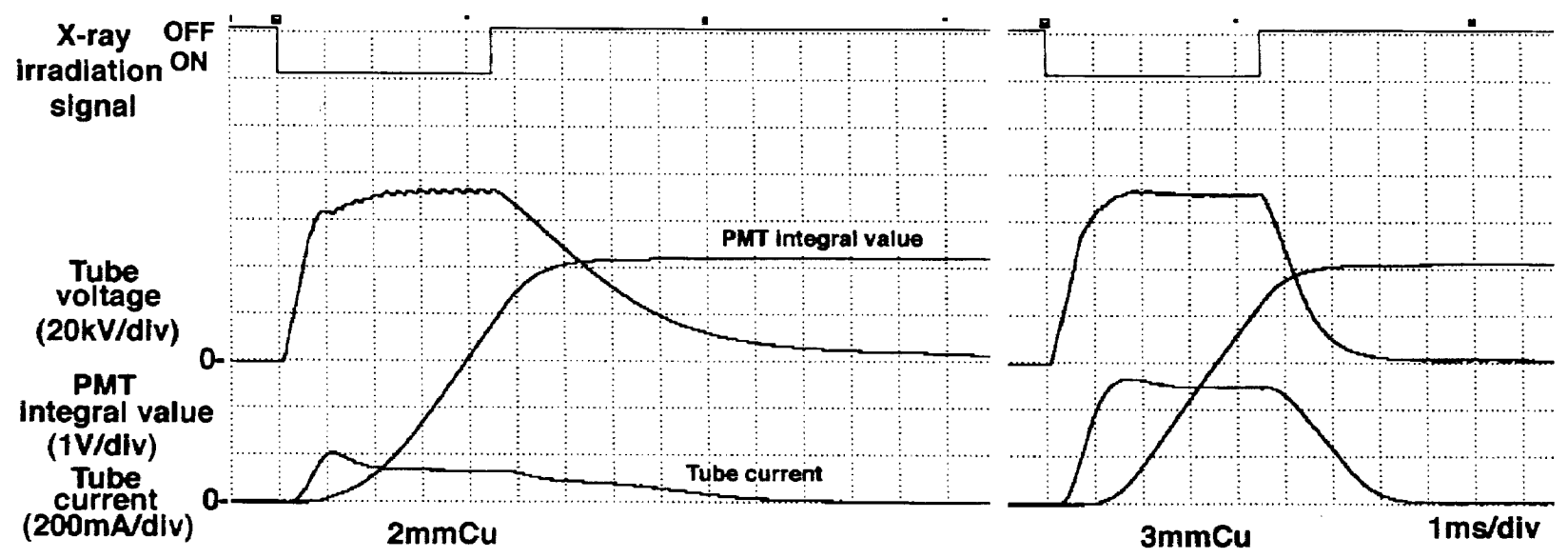

Fig. 2 Waveform of tube voltage, tube current, $x$-ray irradiation signal and PMT integral value (apparatus 1). 


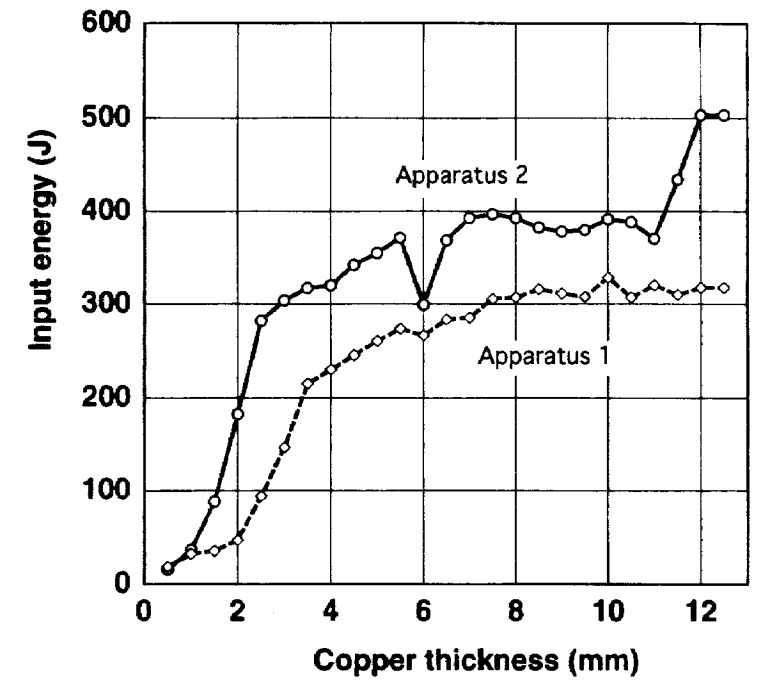

Fig. 3 Relationship between copper thickness and energy input to the $x$-ray tube.

$6 \mathrm{~mm}$ の間で $600 \mathrm{~mA}$ 台を示し, それ以上では減少す る。撮影時間の最短は $2.0 \mathrm{~ms} ゙$ あり，6.2 msおよび $7.6 \mathrm{~ms}$ 付近に変移の少ない領域がある。最長は $9.9 \mathrm{~ms}$ 示した．波形の例をFig.5に示す．1F当たりのエネル ギーをFig.3に示す．銅板 $6 \mathrm{~mm}$ で落ち込みがある。

\section{5-2 被写体厚変化時のX線条件の応答特性}

\section{5-2-1 装置 1 のPMTの出力積分值とフィルム濃度の} 関係

PMTの出力積分值とフィルム濃度の関係をFig.6に 示す. 自動露出制御が正常に動作している時のPMTの

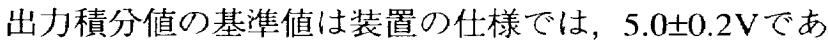
る。この時のフィルム濃度が 0.70 になるように，シネ カメラの絞りと現像処理条件を設定した。 以下の装置 1 のフィルム濃度は, PMTの出力積分值から Fig.6を 使って換算した。

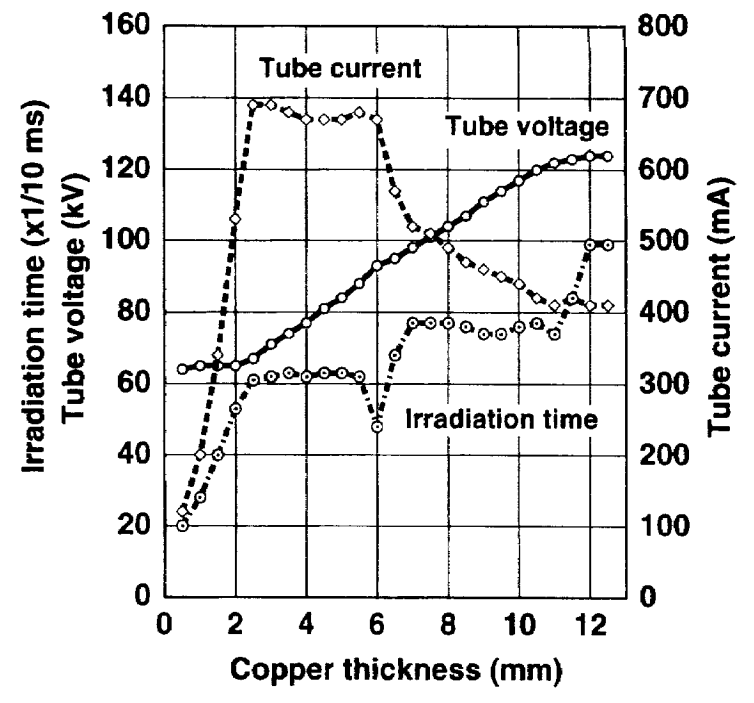

Fig. 4 Relationship between copper thickness and tube voltage, tube current and irradiation time at stability (apparatus 2).

\section{5-2-2 装置 1 の被写体厚增加に対する応答}

被写体扦入前後の銅板厚とX線条件拈よび挿入時か ら安定に戻るまでのフレーム数の例をTable 1 に示 す。そのうち、銅板 $3 \mathrm{~mm}$ から $7 \mathrm{~mm}$ になった最初を $1 \mathrm{~F}$ 目とした後の時間的変化を Fig.7に示す．被写体挿入 により，5.1VだったPMTの積分值が，1F目で1V以下 になる。3F目に管電流の設定值が $490 \mathrm{~mA} ら 710 \mathrm{~mA}$ (許容最大值)になるが, 実測值は12Fかかって到達す る。管電圧は $5 \mathrm{~F}$ 目から $3 \mathrm{kV} / \mathrm{F}$ 以下の変化率で, $\mathrm{PMT} の$ 積分值が基準値になるまで上昇し続ける。

銅板 $3 \mathrm{~mm}$ から $5 \mathrm{~mm}$ への変化の波形をFig.8に示す. $2 \mathrm{~F}$ と $3 \mathrm{~F}$ の間に管電流の設定值が700mAになる。 $5 \mathrm{~F}$ 目 から管電圧が上昇し始め， $84 \mathrm{kV}$ まで達して適正フィ ルム濃度になる、銅板 $3 \mathrm{~mm}$ から $4 \mathrm{~mm}$ への変化の仕方 も同様である。

銅板 $4 \mathrm{~mm}$ から $7 \mathrm{~mm}$ の変化では, 管電流はあまり変化

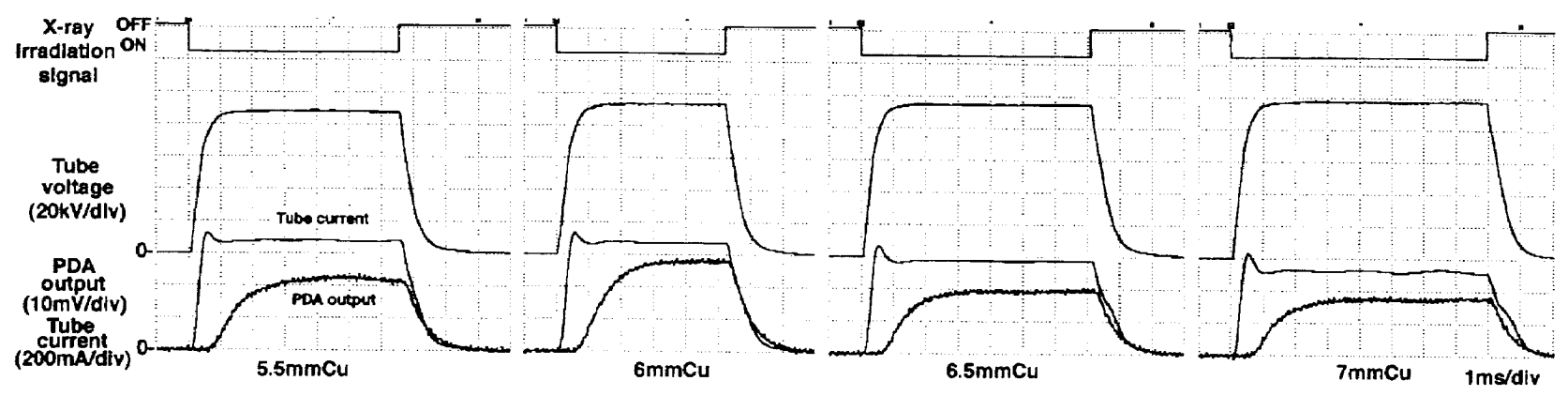

Fig. 5 Waveform of tube voltage, tube current, $x$-ray irradiation signal and PDA output value (apparatus 2). 


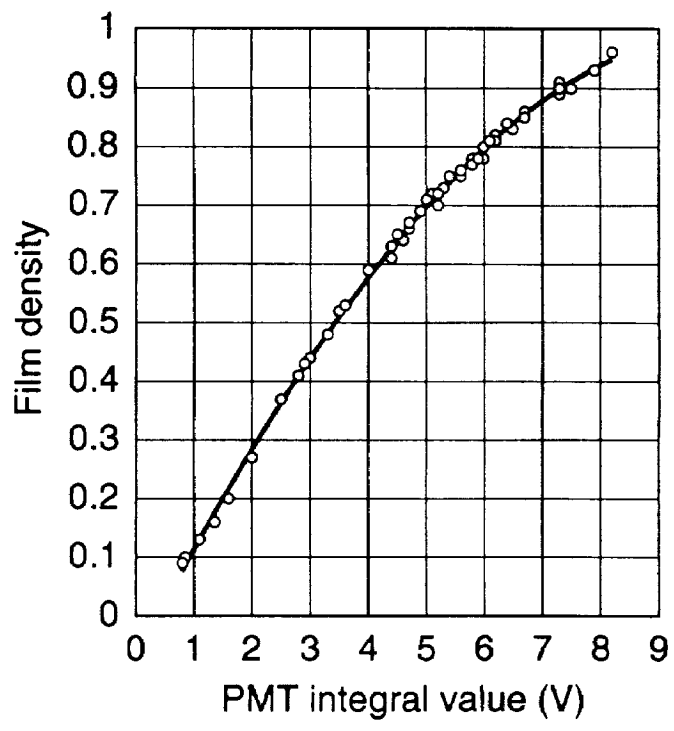

Fig. 6 Relationship between PMT integral value and film density.

せず，篇電理が78kVから $96 \mathrm{kV}$ まで $3 \mathrm{kV} / \mathrm{FW下}$

で上昇して，17Fで適正フィルム濃度となる。

\section{5-2-3 装置 1 の被与体厚減少に対する応答}

被写体引き抜き前後の銅板厚亡, X線条件 および引き抜きから安定に戻るまでのフレー 么数の例をTable 2 に示す.

銅板 $4 \mathrm{~mm}$ から $3 \mathrm{~mm}$ への時間的变化をFig.9に 示す。管電王が5F目まで $2 \mathrm{kV} / \mathrm{F}$ 以下で下降して $72 \mathrm{kV}$ だ下がるが，PMTの積分值はまだ $8 \mathrm{~V}$ を示す。7F目から管電流の設定值が $430 \mathrm{~mA}$, さらに $350 \mathrm{~mA}$ へと 2 回減少子る.そして, 実 測值が減少を開始してから5F目の540mAで適 正フィルム濃度になる。しかし，その後も実 測值が設定值に向かって减少し続けるため, フィルム濃度は過小となる。そ礼を補正するよ うに，管電压が少し上昇する。このような猧渡 現象をもう一度繰り返して適正安定になる。

$5 \mathrm{~mm}$ から $3 \mathrm{~mm}$ ，および $7 \mathrm{~mm}$ から $3 \mathrm{~mm}$ の变化 でも，そ机ぞ狆10および20Fかかって，管電圧 が73および74kVまで下降する。その後の管電 压，管電流の变化の仕方は上述の場合とほぼ 同じである。

銅板 $7 \mathrm{~mm}$ から $4 \mathrm{~mm}$ への変化では，3F目から 管電生が下降し始め，78kVになったところで 適正フィルム濃度になる。管電流は大きく変 化しない。この場合は，11Fにわたって適正濃 度+0.3以上が続いた。
Table 1 Subject thickness and $x$-ray conditions before and after subject thickness was increased and stability resumed (apparatus 1 ).

\begin{tabular}{lcccc}
\hline & $\begin{array}{c}\text { Subject } \\
\text { thickness } \\
(\mathrm{mmCu})\end{array}$ & $\begin{array}{c}\text { Tube } \\
\text { voltage } \\
(\mathrm{kV})\end{array}$ & $\begin{array}{c}\text { Tube } \\
\text { current } \\
(\mathrm{mA})\end{array}$ & $\begin{array}{c}\text { Stability } \\
\text { resumed } \\
\text { (frame) }\end{array}$ \\
\hline $\begin{array}{l}\text { Before fluc. } \\
\text { After fluc. }\end{array}$ & 3.0 & 72 & 480 & 11 \\
\hline Before fluc. & 3.0 & 80 & 660 & 12 \\
After fluc. & 5.0 & 73 & 500 & 12 \\
\hline Before fluc. & 3.0 & 75 & 500 & 20 \\
After fluc. & 7.0 & 99 & 720 & \\
\hline Before fluc. & 4.0 & 78 & 710 & 17 \\
After fluc. & 7.0 & 96 & 740 & \\
\hline
\end{tabular}

fluc. : flucluation
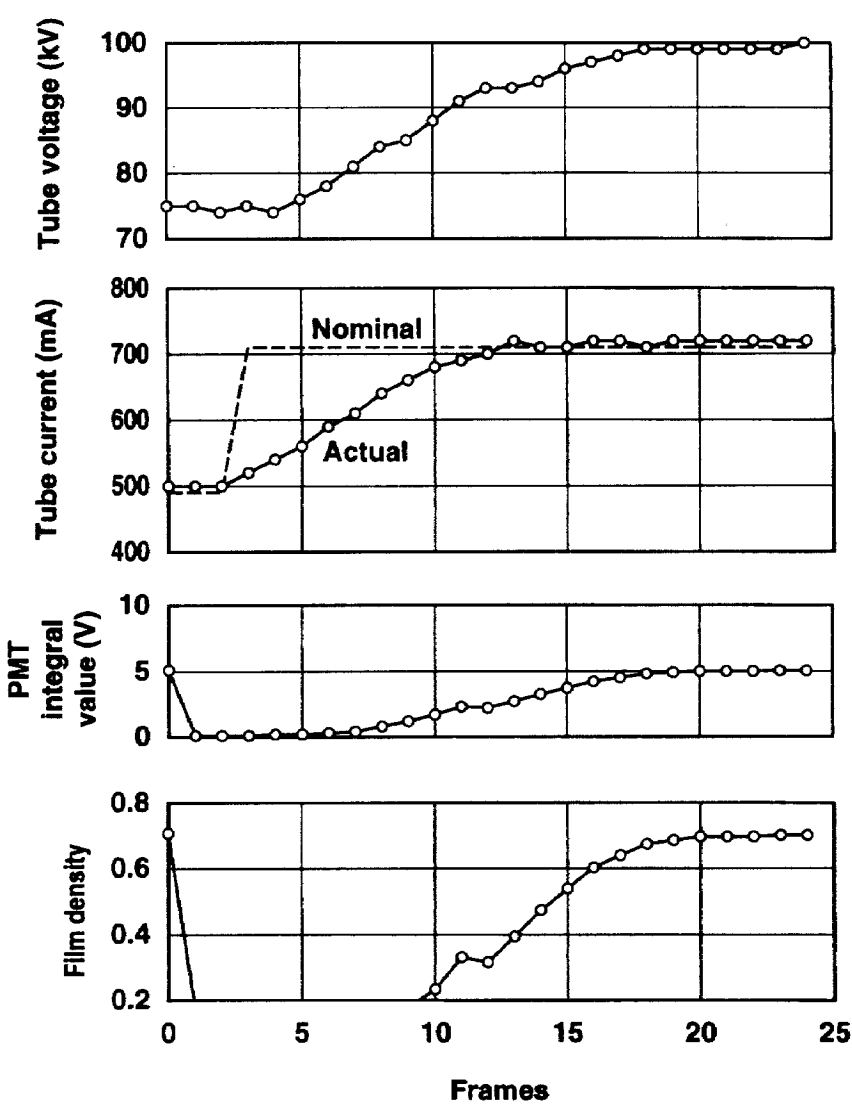

Fig. 7 Tube voltage, tube current, photomultiplier integral value and film density when subject thickness was changed from $3 \mathrm{mmCu}$ to $7 \mathrm{mmCu}$ (apparatus 1). 


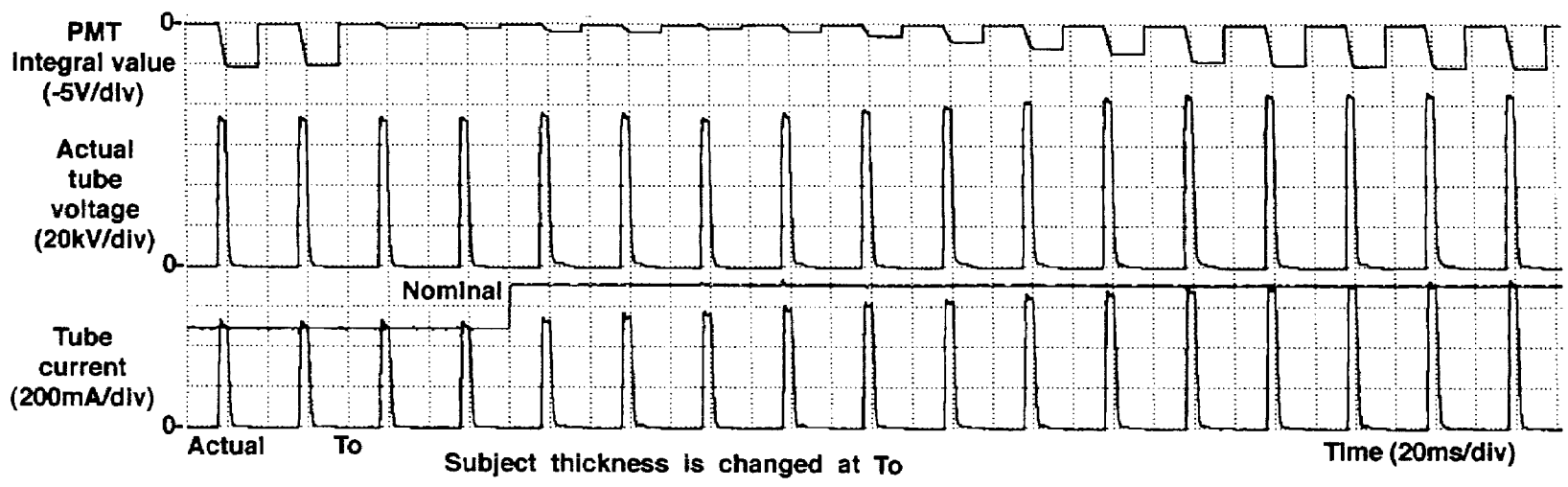

Fig. 8 Waveform of PMT integral value, tube voltage and tube current (nominal and actual) for time. Subject thickness was increased from $3 \mathrm{mmCu}$ to $5 \mathrm{mmCu}$ at point To.

\section{5-2-4 装置 2 の被写体厚増加に対する応答}

被写体挿入前後の銅板厚と，安定適正時のX線条件 および挿入時から安定に戻るまでと，最初に適正值を 通過するフレーム数の例をTable 3 に示す.

銅板 $1.5 \mathrm{~mm}$ から $5.5 \mathrm{~mm}$ への時間的変化をFig.10に示 す。1F目で撮影時間は9.9msに達する。3F目までに管 電圧は65kVから $80 \mathrm{kV} に 上$ 昇する。管電流の設定值は 2F目に350mAから690mAに上昇し，4F目で管電流の 実測值は設定值に達するが，フィルム濃度はまだ不足 している．6F目で管電圧がさらに $8 \mathrm{kV}$ 上昇するがフィ ルム濃度はまだ不足している。7F目に $2 \mathrm{kV}$ 上昇して撮 影時間が7.6msになり，フィルム濃度がほぼ適正とな る.その㖟は撮影時間が変化して，11F目から安定適 正値になる。

管電流の実測值は $2 \mathrm{~F}$ 目から $4 \mathrm{~F}$ 目で $290 \mathrm{~mA}$ 上昇す る.その時の波形を見ると $2 ， 3 \mathrm{~F}$ 目では，1パルス内 でも管電流值が上昇していることが分かる(Fig.11).

銅板 $1 \mathrm{~mm}$ から $2.5 \mathrm{~mm}$ へ変化では管電圧は最初の $7 \mathrm{~F}$

Table 2 Subject thickness and $x$-ray conditions before and after subject thickness was reduced and stability resumed (apparatus 1 ).

\begin{tabular}{|c|c|c|c|c|}
\hline & $\begin{array}{l}\text { Subject } \\
\text { thickness } \\
(\mathrm{mmCu})\end{array}$ & $\begin{array}{c}\text { Tube } \\
\text { voltage } \\
(\mathrm{kV})\end{array}$ & $\begin{array}{l}\text { Tube } \\
\text { current } \\
(\mathrm{mA})\end{array}$ & $\begin{array}{l}\text { Stability } \\
\text { resumed } \\
\text { (frame) }\end{array}$ \\
\hline Before fluc. & 4.0 & 78 & 710 & \multirow{2}{*}{21} \\
\hline After fluc. & 3.0 & 73 & 430 & \\
\hline Before fluc. & 5.0 & 85 & 720 & \multirow{2}{*}{27} \\
\hline After fluc. & 3.0 & 74 & 390 & \\
\hline Before fluc. & 7.0 & 100 & 710 & \multirow{2}{*}{36} \\
\hline After fluc. & 3.0 & 75 & 480 & \\
\hline Before fluc. & 7.0 & 98 & 700 & \multirow{2}{*}{17} \\
\hline After fiuc. & 4.0 & 78 & 710 & \\
\hline
\end{tabular}

で $5 \mathrm{kV}$ 上昇する。管電流の設定值は2F目で $250 \mathrm{~mA} ４ 4 \mathrm{~F}$ 目でさらに220mA増加する。実測值は，1F目の $210 \mathrm{~mA}$ から $5 \mathrm{~F}$ 目までに640mAになる。

また，銅板 $2.5 \mathrm{~mm}$ から $5.5 \mathrm{~mm}$ の変化は管電流は常にほ ぼ最大 $(700 \mathrm{~mA}$ 前後)で，管電圧が $8 \mathrm{~F}$ 目までに7kV/F， または $8 \mathrm{kV} / \mathrm{F} の$ 上昇率を含み $23 \mathrm{kV}$ 上昇する。

\section{5-2-5 装置 2 の被写体厚減少に対する応答}

被写体引き抜き前後の銅板厚と安定適正時のX線条 件および引き抜きから安定に戻るまでと最初に適正值 を通過するフレーム数の例をTable 4に示す。

三つの場合で，6ms台だった撮影時間が1F目で $2 \mathrm{~ms}$ 未满になる。この変化だけでも露光量は $1 / 3$ 以下 になる。

銅板 $5.5 \mathrm{~mm}$ から $1.5 \mathrm{~mm}$ への変化をFig.12に示す。最 初に管電压が $24 \mathrm{kV}$ 降する。7F目から管電流の設定 值が $690 \mathrm{~mA} ら 310 \mathrm{~mA}$ へと減少するが，実測值は徐 々に減少する。7F目からはフィルム濃度が微過小にな る。この時，撮影時間が徐々に延びるが，フィルム濃 度が少し低い状態が続く。

銅板 $2.5 \mathrm{~mm}$ から $1.0 \mathrm{~mm}$ への変化では，管電圧は 60kV台を維持する。690mAだった管電流の設定值が $1 \mathrm{~F}$ 目から急激に減少し，5F目では220mAとなる。実 測值は34Fに渡り徐々に下降する。しかし，撮影時間 の調整により，7F目以降ではフィルム濃度は適正值士 0.10 範囲に入り，13F以降で安定適正になる。

銅板 $5.5 \mathrm{~mm}$ から $2.5 \mathrm{~mm}$ への変化では，7F目までに 管電圧が $88 \mathrm{kV}$ から66kVに下降する。管電流は最大の ままで，5F目でフィルム濃度が適正值以下になるが 管電圧が下降するのでさらに低下する，しかし，管電 圧，管電流の設定值は変化せず，撮影時間が徐々に長 くなって適正フィルム濃度になる，最終的には6 ms台 になる。 


\section{6. 考 察}

\section{6-1 X線条件の被写体厚特性}

装置 1 において撮影時の管電流が $300 \mathrm{~mA}$ 以 下の時は，X線管への高電圧用ケーブルに静 電容量があるために，管電流の減衰が緩やか になる。そ㞦に伴い, 管電压の減衰も緩やか になり，X線照射信号が常に一定でも撮影時 間が長くなる。

装置 1 の1F当たりの入力エネルギーは，銅 板 $6 \mathrm{~mm}$ を除き $8.5 \mathrm{~mm}$ まで増加して，それ以上 でははほぼ一定である。被写体厚特性では，写 真効果の大きい管電压が単調に増加する。管 電流は銅板 $8.5 \mathrm{~mm}$ 以降で減少して, 入力工 ネルギーを増やさずに管電圧の上昇を可能に する。

装置 2 の銅板 $5.5 \mathrm{~mm}$ から $6 \mathrm{~mm}$ に移行すると ころでのX線条件は，管電流はそれぞれ 680mAと670mAでほほ同じである。管電圧は $88 \mathrm{kV}$ から $93 \mathrm{kV}$ 人上昇している。この時の PDAによるI.I. 出力蛍光面の計測值は, $22 \mathrm{mV}$ 加 $27 \mathrm{mV}$ 人約 $23 \%$ 增加して扔り，I.I.を用い た間接撮影においても管電圧の上昇は大きな 写真効果を与えることが分かる。また，その 分，撮影時間は後者が前者に比べて $23 \%$ 短 く, 結果として, 銅板 $6 \mathrm{~mm}$ での自動露出撮影時の1F 当たりの人力エネルギーは, 銅板 $5.5 \mathrm{~mm}$ りも約 20 \%少なくて济む。

それに続く銅板 $6.5 \mathrm{~mm}$ 抢よ゙゙ $7 \mathrm{~mm}$ の管電圧は，そ れぞれ95kV，98kVでPDAの出力值はそ礼ぞ机 $19 \mathrm{mV}, 18 \mathrm{mV}$ である.1F当たりのフィルムへの露光 量に相当する值として, PDAの出力波形と $0 \mathrm{mV}$ 基 線で囲古面積を求めると銅板 $5.5,6,6.5,7 \mathrm{~mm}$ に対

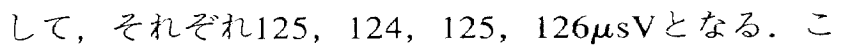
の值から，そ扎ぞれの場合で, ほぼ同じフィルム濃度 を得ることが確認できる。

銅板 $5 \mathrm{~mm}$ 以下でも管電圧を高 く設定すれば，もっと少ない入 力エネルギーで撮影できるが， 沃素を含んだ造影剂を用いる検 查では70kV付近での撮影が理想 的なので，入力エネルギーが高 くなるが，あえて管電压を下げ ていると考えら扎る。

銅板が7〜11 mmの範囲では， 人力エネルギーは，ほぼ一定で あるが，12mmでは，25\%以上 増加し，1F当たり500Jを越え る. $12.5 \mathrm{~mm}$ になってもX線条件
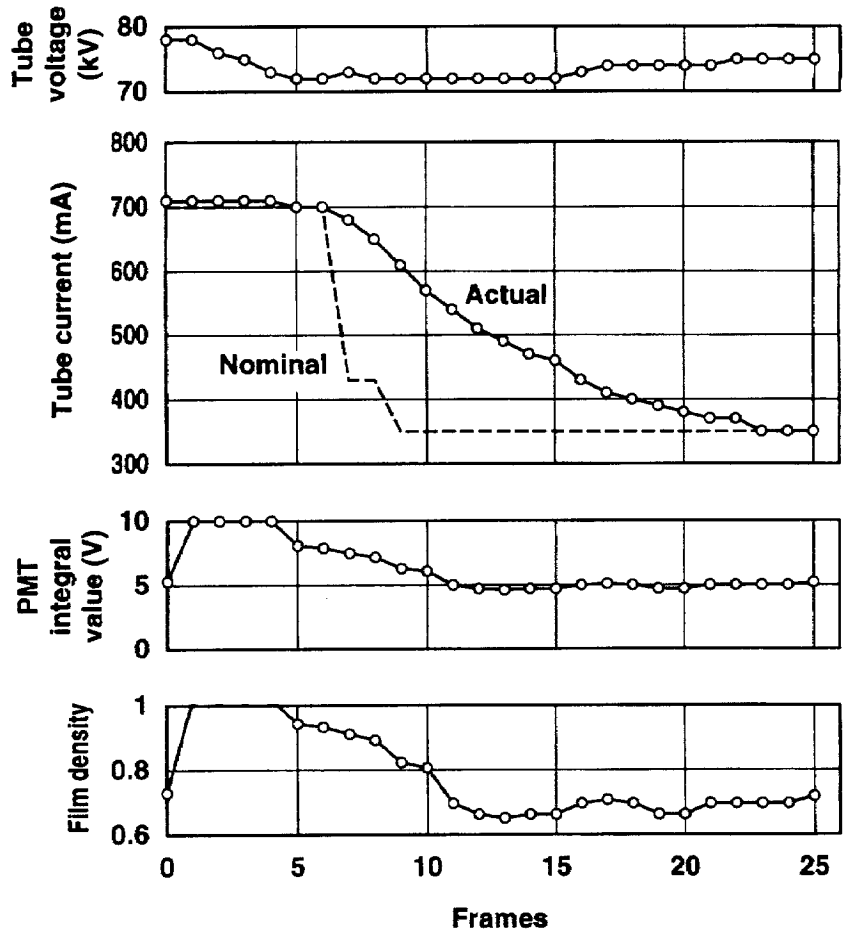

Fig. 9 Tube voltage, tube current, photomultiplier integral value and film density when subject thickness was changed from $4 \mathrm{mmCu}$ to $3 \mathrm{mmCu}$ (apparatus 1 ).

は変化せず，フィルム濃度は露光量不足になるので， この人力エネルギーがこの装置の最大であることがわ 加る

結果的には，銅板3１1 mmの広い範囲で，X線条件 は大きく変化するが，入力エネルギーは最大值の約60 \%から約 $80 \%$ の範囲内にあたる300J台を保つ。

\section{6-2 被写体厚変化時の応答特性}

装置1の自動露出制御は管電圧と管電流で行われる. 被写体厚増加時に管電流の大きな変化を伴う場合, まず，管電流の設定值が許容の最大值まで上昇し，そ
Table 3 Subject thickness and $x$-ray conditions before and after subject thickness was increased and stability resumed (apparatus 2 ).

\begin{tabular}{|c|c|c|c|c|c|c|}
\hline & $\begin{array}{l}\text { Subject } \\
\text { thickness } \\
\text { (mmCu) }\end{array}$ & $\begin{array}{c}\text { Tube } \\
\text { voltage } \\
(k V)\end{array}$ & $\begin{array}{l}\text { Tube } \\
\text { current } \\
\text { (mA) }\end{array}$ & $\begin{array}{l}\text { Pulse } \\
\text { width } \\
\text { (ms) }\end{array}$ & $\begin{array}{c}\text { First cross } \\
\text { of proper } \\
\text { value } \\
\text { (frame) }\end{array}$ & $\begin{array}{l}\text { Stability } \\
\text { resumed } \\
\text { (frame) }\end{array}$ \\
\hline Before fluc. & 1.0 & 64 & 210 & 2.7 & \multirow{2}{*}{6} & \multirow{2}{*}{11} \\
\hline After fluc. & 2.5 & 68 & 700 & 6.8 & & \\
\hline Before fluc. & 2.5 & 68 & 700 & 6.7 & \multirow{2}{*}{8} & \multirow{2}{*}{10} \\
\hline After fluc. & 5.5 & 88 & 680 & 7.1 & & \\
\hline Before fluc. & 1.5 & 65 & 350 & 4.1 & \multirow{2}{*}{7} & \multirow{2}{*}{11} \\
\hline After fluc. & 5.5 & 90 & 700 & 7.1 & & \\
\hline
\end{tabular}



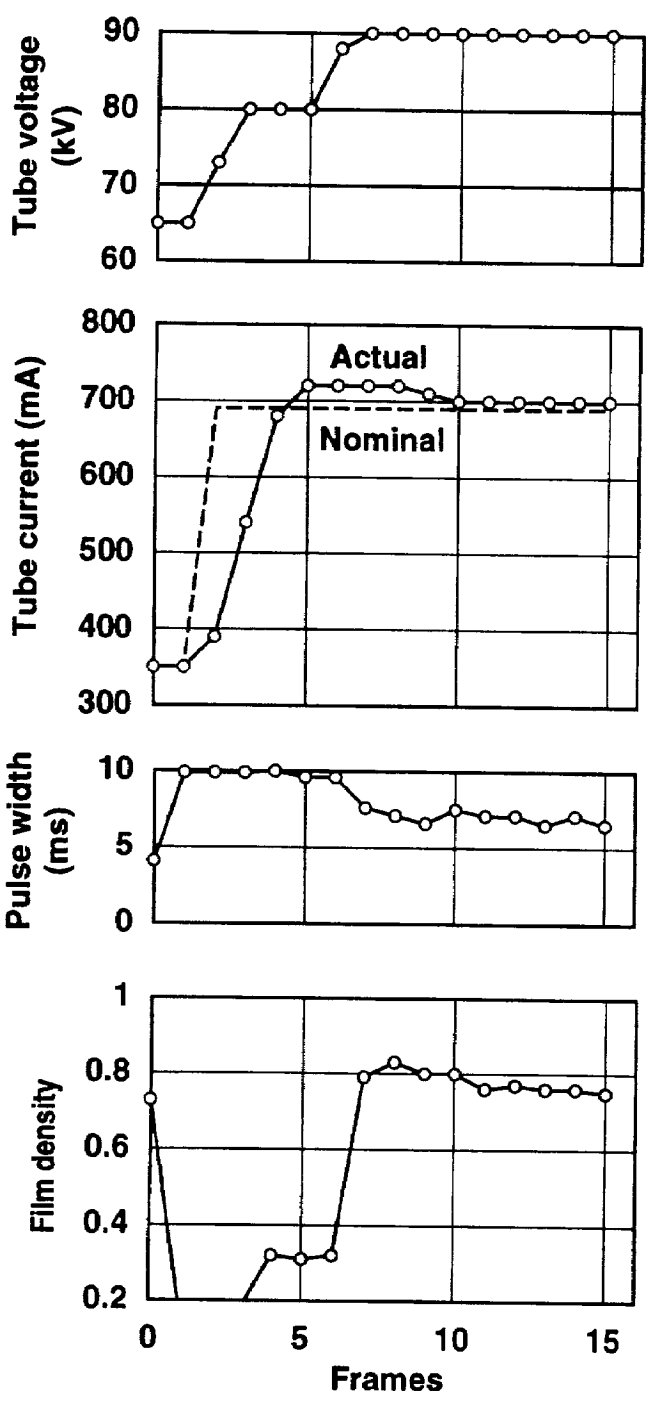

Fig. 10 Tube voltage, tube current, irradiation time and film density when subject thickness was changed from $1.5 \mathrm{mmCu}$ to $5.5 \mathrm{mmCu}$ (apparatus 2).
机でも露光量が足りないと，管電圧が上昇し始める。 この場合，管電流の実測値の上昇は䐅く，露光量は不 足しているので，比較的速く管電土が上昇し始める。

管電圧の高いところから被写体厚が減少すると，管 電圧が $73 \mathrm{kV}$ 付近に下がってから管電流の設定值が減 少し始める，管電流の減少はX線管の陰極のフィラメ ント温度の低下によるので，管電圧の変化に比べて時 間がかかる。

管電圧の変化は3kV/F以下であり，管電流の実測值 の上昇率は最大 $30 \mathrm{~mA} / \mathrm{F}$ で，平均約 $20 \mathrm{~mA} / \mathrm{Fである。下}$ 降率は最大 $50 \mathrm{~mA} / \mathrm{F}$ で平均䄪 $25 \mathrm{~mA} / \mathrm{F} ゙$ ある。

被写体厚変化の前後で，管電流の変化が少なく，管 電压の変化だけで済む場合には応答が早い。

X線制御装置へのフィードバックは, PMTの出力積 分値と基準值の比較によるX線条件の増加，または減 少の信号のみなので，被写体厚变化前㣪の差が大きい ほどX線条件の差が大きくなり，適正になるまでに時 間がかかる。

装置 2 の自動露出制御は，管電圧と管電流および撮 影時間で行わ饥る。

被写体厚増加時には，1F目から撮影時間が許容最

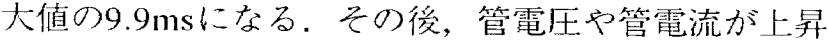
して，フィルム濃度が最初に適正値より過小から過大 に転じるフレームで撮影時間が $9 \mathrm{~ms}$ 以下になる。この ことから，最大撮影時間でも露光量が不足する場合以 外では，各フレームごとにPDAの積分值が適正值に なったところで，X線時限信号を切るような制御をし ていることが尔かる。そして，被写体厚変化時の応答 は，管電圧と管電流の設定值が迅速に大きく变化し て，その後あまり変化しない。その結果，被写体厚变 化後の安定時のX線条件は，透視後撮影した時のX線

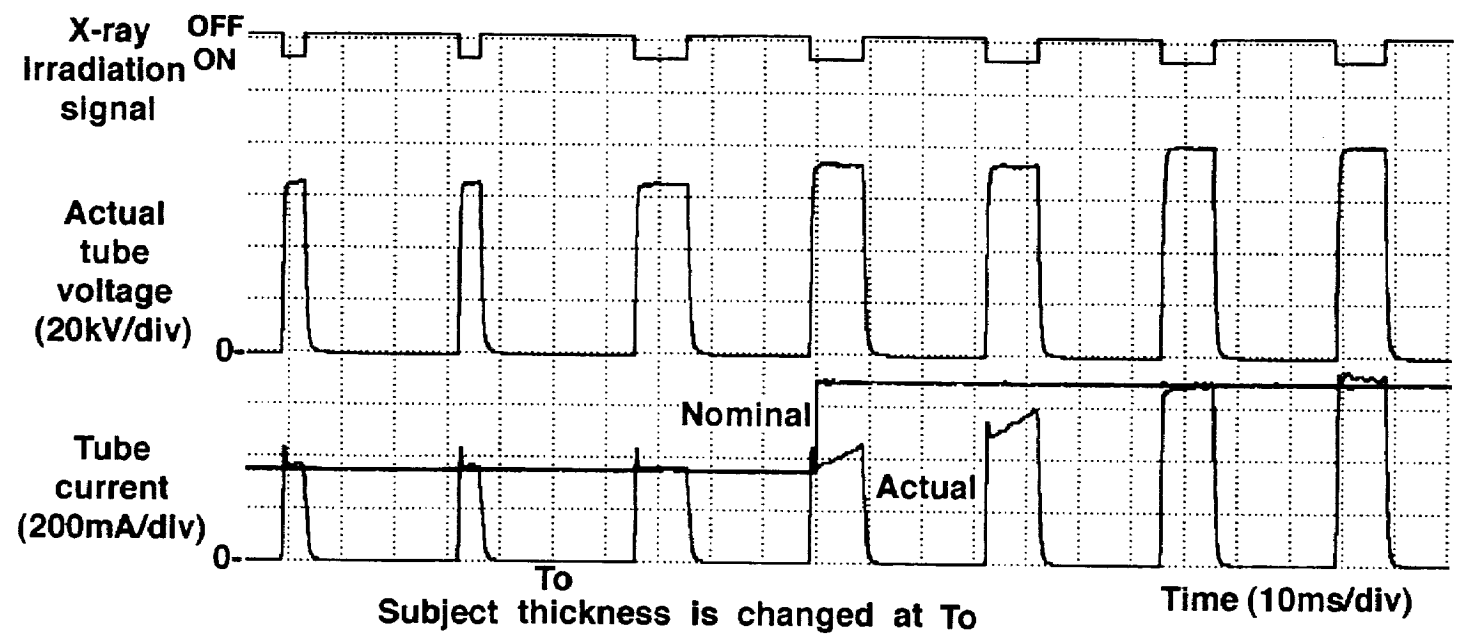

Fig. 11 Waveform of exposure signal, tube voltage and tube current (nominal and actual) for time. Subject thickness was increased from $1.5 \mathrm{mmCu}$ to $5.5 \mathrm{mmCu}$ at point To. 
条件 (被写体厚特性測定時) と異 なる場合がある。

銅板厚 $1.5 \mathrm{~mm}$ から $5.5 \mathrm{~mm}$ への 変化と銅板厚 $1 \mathrm{~mm}$ から $2.5 \mathrm{~mm}$ の 変化を比べると, 変化直瑷の露 光量不足に対して，両者とも管 電流は5F以内に大幅に上昇して いる。管電压は前者が急激に上 昇するが，㣪者の上昇は緩やか である。この時のPDAの積分值 を瞬持值の波形から概算する と，前者の場合では，1Fから $5 \mathrm{~F}$ 日までがすべて0である。一

方, 後者の1, 2F目は直前( $0 \mathrm{FB}$ ) の適正值の 約 $25 \%$ を示している。こ扎ら加ら，PDAの積 分值の大小をフィードバックして，管電压の 变化率在設定していると考えら机る。

管電压の变化率は最大 $8 \mathrm{kV} / \mathrm{F}$ であり，大き な与真効果の变化が期待できる。また，管電 王の大きな变化がある場合は，被写体厚変化 後の最初の8F位までで，その後の変化率は小 さい、管電流の下降は管電圧が $63 \mathrm{kV}$ になっ からで, 装置 1 と同様, その变化率は小さく

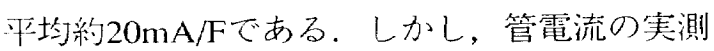
值が設定值にむかう過渡期に抏いても，撮影 時間が調節さ扎て露光量は適正值になり得 る。また，管電流の上昇は速く最大 $140 \mathrm{~mA} / \mathrm{F}$ である。こ礼は，フィラメントの交流加熱回 路のインバー夕周波数が装置 1 の最大 $10 \mathrm{kHz}$ に対し, 装置 2 は最大 $44 \mathrm{kHz}$ と大きくなって 扣り, 素早い変化を可能にしている.

まとめる上，被写体厚の変化に対して，管 電压，管電流の設定值が変化して，その実測 值が $8 \mathrm{~F}$ 以内に追従する．撮影時間は各フレー ムごとに調整され，変動中の初期には大幅に 変わり，㣪期には微調整を行う。その結果， 被写体厚増加時には，堌加した厚さにかかわ らず約10Fで適正濃度に戻る。被写体厚減少 時には，管電圧の大幅な下降や管電流の連続 的な下降によって，10F位に適正值を通過し てアンダーシュートする傾向があるが，約 $15 \mathrm{~F}$ で適正露光量に原る。適正濃度に戻る时 間は，装置1に比べかなり短いが，いな゙和も 適正濃度值の前後を減衰振動する傾向がある。

\section{7. 结 語}

X線シネ撮影の自動露出制御では，被写体厚が増加 する上管電圧が上昇する。管電圧は写真効果に大きく
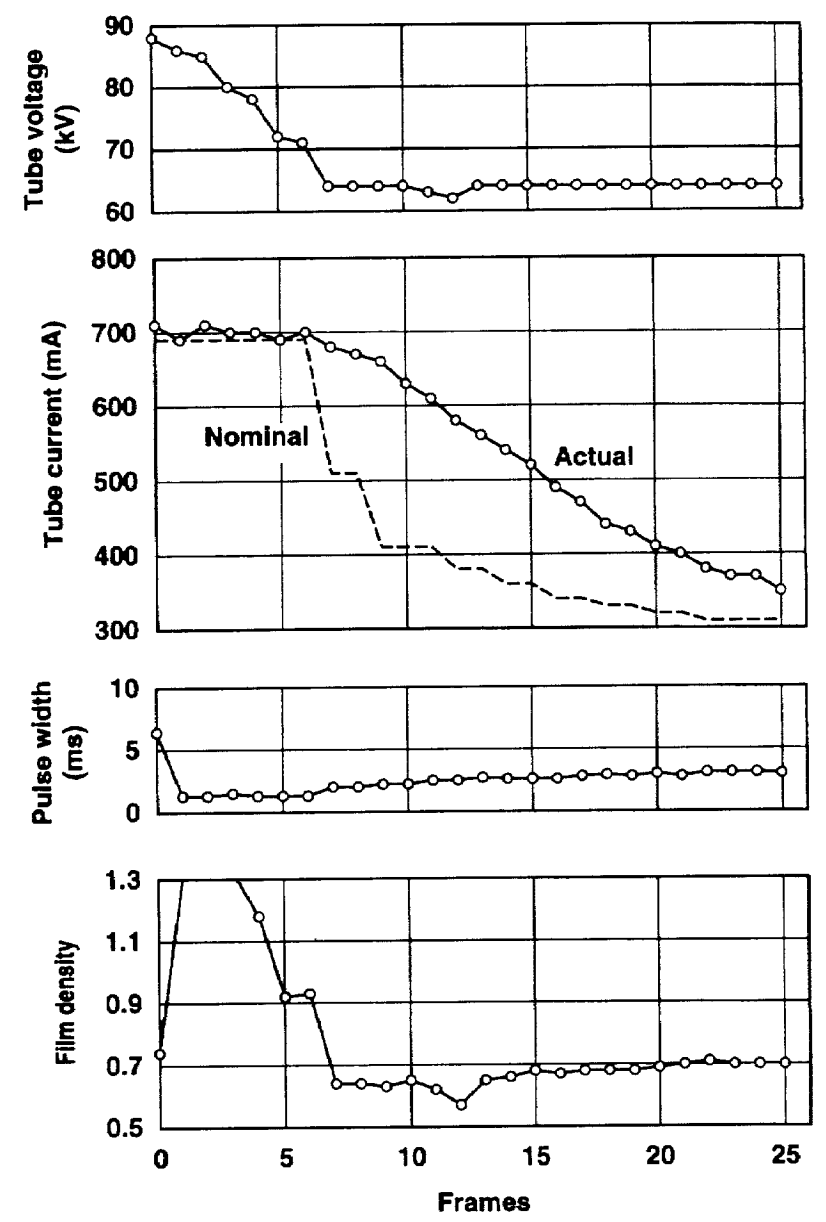

Fig. 12 Tube voltage, tube current, irradiation time and film density when subject thickness was changed from $5.5 \mathrm{mmCu}$ to $1.5 \mathrm{mmCu}$.

寄与するので，被写体が厚くなるにもかかわらず，1F 当たりのX線管への入力エネルギーが小さくなる場合 がある。

被写体厚の急激な变化に対して，X線時限信号が一 定の装置は管電压と管電流の上昇，下降の制御のみ 
で，変化量が増えると適正に戻るまでの時間も確実に 長くなる。そ㞦に対し，撮影時間が変化する装置で

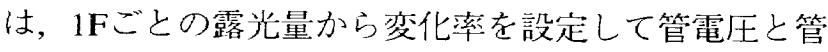

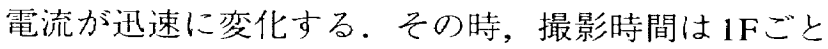
にタイマの役割をして露光量の微調整を行う。そし て，適正に戻るまでの時間は被写体厚の变化量に大き く依存しない。

また，X線管電圧の実測值は，雨装置ともX線制御 装置からの設定值に正確に一致する。管電流の実測値 は，装置2の上昇のみがよく追従するが他の場合は応 答が悪い。
被験者は, X線条件が変化する時の過露光や露光量 不足で画像上診断佂值が少ない場合でも被曝を被る。 このような不要な被曝のない理想的な制御装置をめざ

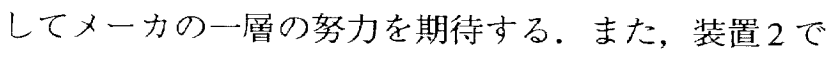
は自動露出制御に用いられる視野上の正確な関心領域 と各領域の荷重值がわからない．撮影対象によって は，ユーザが選択や設定ができ，診断価值のない撮影 を少しでも減らすことができるようにメーカからの情 報提供を望む。

この論文の内容の一部は，第53回放射線技術学会総 会で発表した。

\section{参考文献}

1) 宮崎 茂：IVRと撮影技術一冠動脈形成術に抄ける撮影技 術一. 日放技学誌, 52(6), 773-777, (1996).
2) 勝又三夫：効果一インバータ式X線装置の特性と臨床 4. 循 環器挨査一。日放技学誌, 46(12)，1910-1916，(1990). 